MACIEJ JANOWSKI

Instytut Historii PAN, Warszawa

\title{
JESZCZE RAZ O LELEWELU I KRYTERIACH OCENY KLASYKÓW HISTORIOGRAFII*
}

Z zainteresowaniem przeczytałem odpowiedź Henryka Słoczyńskiego na mój artykuł recenzyjny ${ }^{1}$, poświęcony jego książce o Joachimie Lelewelu Światło $w$ dziejarskiej ciemnicy. Koncepcja dziejów i interpretacja przeszłości Polski Joachima Lelewela (Kraków 2010). Choć przekroczyłem wszelki przyzwoity czas na przygotowanie polemiki, chciałbym się jednak odnieść do kilku spraw. Przyznam, że dotknął mnie zarzut, jakobym nie przeczytał jego książki, jest to bowiem oskarżenie o charakterze etycznym, o nierzetelność naukową. Książkę przeczytałem tak uważnie jak potrafiłem, notując, mażąc ołówkiem i wklejając karteczki z uwagami. Miałem ją na biurku podczas pisania recenzji dla sprawdzania cytatów i różnych fragmentów. Jednak jest oczywistą niemożliwością założenie, że recenzent w pełni panuje nad treścią ponadsześćsetstronicowej książki w trakcie pisania recenzji. Kiedy czytelnik czyta książkę, w głowie tworzy się jakiś jej obraz, który jest wypadkową treści dzieła i oczekiwań, wiedzy, zainteresowań czytelnika itp. W ostatecznym rozrachunku recenzja jest napisana na podstawie tego obrazu - to dotyczy każdej recenzji i chyba każdego recenzenta, a nie tylko mnie. Stąd możliwe są opuszczenia pewnych wątków, a także niezrozumienie pewnych myśli Autora. Przyjmuję więc niektóre szczegółowe zarzuty Autora: rzeczywiście, przywołałem przykład Juliana Ursyna Niemcewicza, który sam Autor także przywołuje w swojej książce. Rzeczywiście, nie pamiętałem podczas pisania

* H.M. Słoczyński, Historyk, fakt, pokora, KH 123, 2016, 3, s. 523-551 (odniesienie do polemiki oznaczam S).

${ }^{1}$ M. Janowski, Król nie jest nagi. Wokół kryteriów ocen klasyków historiografii, KH 121, 2014, 4, s. 897-920. 
recenzji o zdaniu ze strony 302, dotyczącym mistycyzmu Lelewela, które Autor przypomniał mi w swojej odpowiedzi (chociaż podczas lektury zaznaczyłem je sobie ołówkiem). Przepraszam. Zarazem, przyjmując te szczegółowe zarzuty, podtrzymuję swój pogląd ogólny. Otóż Słoczyński podkreśla w swej odpowiedzi, że nie stawia Lelewelowi różnych zarzutów, o których pisałem w moim artykule, a zatem część mojej polemiki jest bezprzedmiotowa. Pisze: „Na korzyść Lelewela staram się tłumaczyć niemal wszystko" (S531). Moje wrażenie jest odmienne. Jeszcze raz, na potrzeby tej odpowiedzi, zajrzałem do tekstu książki i wydaje mi się oczywiste, że Autor krytycznie ocenia postawę Lelewela przed rokiem 1830 i krytycznie ocenia jego intuicjonistyczną metodologię. Czytelnicy książki sami to osądzą.

Autor krytykuje moje stwierdzenie o autonomii myśli historycznej i myśli politycznej Lelewela, dając przykłady, jak jego poglądy historyczne i polityczne w wielu wypadkach się pokrywają i jak mogą być wzajemnie wyjaśniane. Te przykłady są jak najbardziej trafne, ale nie dotyczą mojej tezy. Chodzi o to, że między poglądami historycznymi a politycznymi (kogokolwiek, nie tylko Lelewela) nie ma nigdy prostej relacji, ponieważ te same poglądy historyczne mogą u różnych autorów służyć usprawiedliwieniu najróżniejszych, często diametralnie przeciwnych poglądów politycznych. Z tego powodu trzeba zachowywać ostrożność przy wyjaśnianiu czyichś poglądów historycznych poglądami politycznymi i na odwrót. To mam na myśli, mówiąc o autonomii obu sfer.

Innym przedmiotem dyskusji jest kwestia „matematycznej utopii” wieku oświecenia (S525): to, co Autor określa jako „matematyczną utopię", ja skłonny byłbym raczej określić mianem funkcjonalizmu, i widzieć w tym podejście antycypujące późniejszy rozwój antropologii. Wszystkie przykłady przytoczone przez Autora w odpowiedzi na moje omówienie dadzą się w moim przekonaniu odczytać jako przejawy podejścia funkcjonalistycznego, rozumianego jako założenie, że społeczeństwo jest systemem, w którym najróżniejsze zjawiska współzależą od siebie, a wszelkie spełniają - poza swoją funkcją bezpośrednio widoczną - także i funkcję głębszą, stabilizującą system społeczny. Zadaniem badacza jest tę ukrytą funkcję odkryć i opisać. Skoro jednak Autor pisze w swej odpowiedzi, że nie uważa owej „matematycznej utopii” za centralny element myśli oświecenia, to zapewne w tym punkcie różnica poglądów między nami jest mniejsza, niż się na początku wydawało.

Przy okazji, jeśli jesteśmy przy oświeceniu: „czy pogląd o ahistoryzmie wieku świateł [--] znalazł się już w lamusie błędnych idei?” pyta Autor (S524). Tu nie ma żadnej instancji orzekającej, to zależy od badacza. Niektórzy sprzeciwiają się mu zasadniczo, jak np. John Burrow 
w 2007 r.: „Było dziewiętnastowieczną kliszą, że historycy z XVIII w. nie mieli zdolności empatycznego współodczuwania z minionymi epokami ani dostrzegania specyfiki ich charakterów moralnych. To jest nonsens"' Tak ostre postawienie sprawy jest pewnie przesadzone, ale podobna myśl, choć łagodniej przedstawiona, przenika np. prace Ulricha Mulacka czy Hannsa Petera Reilla ${ }^{3}$ o historiografii niemieckiej, które podkreślają ciągłość, a nie zerwanie, między myślą historyczną niemieckiego oświecenia a „klasycznym” niemieckim historyzmem z czasów Leopolda Rankego. Podobne wrażenie uzyskuje czytelnik z lektury pierwszego tomu wielkiej pracy Johna Pococka o najróżniejszych kontekstach myśli historycznej Edwarda Gibbona (Barbarism and Religion). Pocock, nie zamazując różnicy między historiografią oświeceniową a dziewiętnastowieczną, wielokrotnie wskazuje na dążenia osiemnastowiecznych historyków do zrozumienia specyfiki badanych epok i krytycznie odnosi się do takiej „metahistorii zarówno oświecenia, jak i historiografii europejskiej, która redukuje wszelkie istotne zjawiska do narracji o przejściu od oświeceniowego naturalizmu do romantycznego [--] historyzmu" ${ }^{4}$. Zresztą nawet sam przywoływany przez Słoczyńskiego Friedrich Meinecke, który tak się przyczynił do rozszerzenia owego obrazu ahistorycznego oświecenia, w swojej klasycznej pracy o genezie historyzmu podkreśla znaczenie oświecenia w tworzeniu się fundamentów tego nurtu myślowego - odnajduje jego elementy u każdego praktycznie wybitniejszego myśliciela oświeceniowego. Myśl niemiecka przełomu XVIII i XIX w., przede wszystkim Herder, Goethe i Ranke, stworzyła nową jakość w postaci niemieckiego historyzmu, ale ta jakość - zdaniem Meineckego - bardzo wiele czerpała $\mathrm{z}$ myśli oświecenia. Tak więc w moim przekonaniu jest uprawnione przypisywanie myśli historycznej oświecenia elementów podejścia, które określamy mianem historyzmu.

Jednym z najważniejszych wątków w mojej recenzji była kwestia jakości myśli historycznej jako kryterium oceny. „Niestety, rzucił on [tj. ja - M.J.]

2 „It was a cliché of the nineteenth century that eighteenth-century historians had no ability to emphatize with past times or recognize their distinctive moral characters. This is nonsense", J. Burrow, A History of Histories. Epics, Chronicles, Romances and Inquiries from Herodotus \& Thucydides to the Twentieth Century, London 2009 (wyd. 1 2007), s. 356.

${ }^{3}$ U. Muhlack, Geschichtswissenschaft im Humanismus und in der Aufklärung. Die Vorgeschichte des Historismus, München 1991; P.H. Reil, The German Enlightenment and the Rise of Historicism, Berkeley 1975.

4 ,a meta-history of both Enlightenment and European historiography which reduces all relevant phenomena to a narrative of movement from an Enlightened naturalism [--] to a romantic [--] historicism...", J. Pocock, Barbarism and Religion. The Enlightenments of Edward Gibbon 1737-1764, t. 2: Narratives of Civil Government, Cambridge, New York 1999, s. 22-23. 
to zawołanie w postaci nic nie mówiącego ogólnika, toteż muszę uznać, że odrzucając moje refleksje czy raczej swoje nietrafne ich rozumienie, nie proponuje nic w zamian" (S544). Spróbuję wyjaśnić rzecz jeszcze raz. Jest coś takiego, jak intelektualna wartość danej wypowiedzi, i ta wartość jest niezależna od prawdziwości tej wypowiedzi, czy nawet od metodologicznej poprawności. Innymi słowy: nieraz napotykamy na takie wypowiedzi, które uważamy za nietrafne, w których jesteśmy w stanie wskazać logiczne błędy w rozumowaniu, a które mimo to uważamy za frapujące. Otóż, jeśli badając dawnego historyka, interesujemy się historią jego myśli (a nie kwestią, na ile jego prace przyczyniły się do przyrostu liczby znanych nam faktów z przeszłości) to wtedy, moim zdaniem, intelektualna wartość wypowiedzi staje się najważniejsza. Nie potrafię podać jej żadnych kryteriów - i zdaję sobie sprawę, że jest to słaby punkt mojej propozycji. Sądzę, że musiałyby to być jakieś kryteria formalne, to znaczy abstrahujące od treści rozumowania danego historyka: może to być użycie do tej pory niedostrzeganych argumentów, porównań czy metafor; może to być zdolność do przeformułowania badanego problemu w sposób do tej pory niespotykany albo połączenia ze sobą zjawisk do tej pory traktowanych przez badaczy oddzielnie. Może to być wreszcie dostrzeżenie wad wcześniejszych sposobów wyjaśniania danego problemu. Propozycja badania jakości myśli jest więc jedynie ogólną dyrektywą orientacyjną, a nie szczegółową receptą postępowania. W tym sensie muszę przyznać rację Słoczyńskiemu, że jest to ogólnik sądzę jednak, że nie jest „nic nie mówiący”, bo może on nakierunkować dzisiejszego badacza na pewien sposób czytania badanego dziejopisa.

Autor podejmuje kwestię empatii i pyta: „Czy historyk winien zrezygnować z tematu, gdy jego krytyczny stosunek ukształtował się w pewnej mierze już wcześniej na podstawie ogólnej wiedzy i własnych przekonań?" (S545). Nie - empatia metodologiczna jest to coś innego niż empatia realnie odczuwana i starałem się o tym napisać wyraźnie. Czy istnieje groźba utraty krytycyzmu (S545)? Istnieje, ale wydaje mi się, że z dwojga złego jest ona mniej groźna niż groźba niezrozumienia badanego autora.

Wyraziłem w mojej recenzji przekonanie, że wpływ Lelewela jest widoczny w polskiej historiografii po dziś dzień. Słoczyński pisze, że trudno mu było go odnaleźć (S544). Wydaje mi się jednak, że pewne ogólne założenia podejścia Lelewelowskiego stały się swoistym dobrem wspólnym dużej części polskiej historiografii. Przecież, jeśli zastanawiamy się, jakie są wpływy myśli Lelewela czy kogokolwiek innego na historiografię polską, to nie może nam chodzić tylko o konkretne odwołania do tradycji Lelewelowskiej (choć jeden taki przykład dałem w swoim tekście), ale o pewną ogólną atmosferę; w tym sensie podtrzymuję swoje 
stanowisko, że duch optymistycznej oceny przedrozbiorowej Rzeczypospolitej, przekonania o żywotności jej demokratycznych instytucji i ducha publicznego jej obywateli jest jak najbardziej obecny w dzisiejszej historiografii. Myślę, że jeśli w ten sposób będziemy widzieć wpływ Lelewela, to jest on truizmem.

Chciałbym podkreślić jeszcze jedną kwestię, którą już wyłożyłem w recenzji, a teraz ją powtórzę wyraźnie. Moje rozmaite zastrzeżenia wobec książki Słoczyńskiego nie zmieniają faktu, że ogólna ocena tej książki jest pozytywna. Stwierdzenie tego w moim poprzednim tekście nie było tylko captatio benevolentiae, ogólnikowym przyznaniem zalet po to, aby tym ostrzej skrytykować; naprawdę uważam, że książka, napisana żywo i z pasją, jest pracą wartościową, ogromnie wzbogacającą naszą wiedzę o jej bohaterze, a to, że ja osobiście się nie zgadzam z niektórymi jej ustaleniami, nie zmienia tej pozytywnej oceny. Naprawdę zabijająca dla materii historycznej nie jest bowiem kontrowersyjność sądów, ale obojętność badacza wobec badanego tematu.

Jest też ogromnie ważne, że Słoczyński podejmuje problem jakości dorobku Lelewela i jego znaczenia dla późniejszej historiografii. Większość historyków historiografii tego nie robi, ograniczając się do analizy koncepcji historycznych badanego autora w kontekście historii intelektualnej badanej epoki. Coraz częściej zaś historia idei rzeczywiście ustępuje miejsca historii dnia codziennego czy też socjologii wiedzy, w których historycy badani są tak jak każda inna grupa społeczna, i ich cechy jako grupy społecznej są ważniejsze niż jakość ich myśli. Nie uważam takich dociekań za nieważne, ale zgadzam się ze Słoczyńskim, że byłaby wielka szkoda, gdyby przysłoniły one badania z dziejów idei. Sądzę jednak, że tak się nie stanie, że badania myśli historycznej będą nadal trwały, a praca Henryka Słoczyńskiego, zarówno przez swe ustalenia, jak i przez prowokowanie do dyskusji, zajmuje w tych badaniach ważne miejsce.

Biog ram: Maciej Janowski - prof. dr hab., kierownik Zakładu Historii Idei i Dziejów Inteligencji w XIX i XX wieku Instytutu Historii PAN w Warszawie; wykładowca Central European University w Budapeszcie; obszar zainteresowań: historia historiografii, Europa Środkowo-Wschodnia w XIX i XX w. 